\title{
ASSESSING AWARENESS LEVEL OF IN-SERVICE COLLEGE TEACHERS REGARDING PROFESSIONALISM
}

\author{
Amna Saleem \\ Lecturer, Department of Education, The Women University, Multan, Pakistan. \\ Email: amna.6105@wum.edu.pk
}

Article History: Received on $12^{\text {th }}$ April 2021, Revised on $23^{\text {rd }}$ April 2021, Published on $27^{\text {th }}$ April 2021

\begin{abstract}
Purpose of the study: The study's intended purpose was to examine the attitude of college teachers towards professionalism and investigate factors affecting teachers' professionalism at the college level.

Methodology: This research nature was descriptive; a simple random sampling technique was used to pick the sample for this research. On a five-point Lickert scale, researchers built a questionnaire and collected data from 340 respondents, including 99 males, 241 females. The researcher employed descriptive and inferential statistics such as mean, frequency, one-way ANOVA, and z-test for data analysis with the help of SPSS.
\end{abstract}

Main Findings: The study's essential results indicate that teachers develop practical lessons by organizing instructional activities and materials intelligently and explaining them in multiple ways and they utilize appropriate inquiry tools according to the nature of the subject and promote self-reflection among students and motivate them to solve their problems themselves.

Applications of this study: The study will be beneficial for the stakeholders in developing an understanding of professionalism. It will provide the prospective teachers with the guidelines regarding constituents of professionalism. The study will provide feedback about the current status of professionalism. The study will highlight missing elements in professionalism to be valued in the future professionalizing project.

Novelty/Originality of this study: This study contributes to helping teachers to understand the meaning of professionalism and factors associated with it and help them to understand their responsibilities in a better way and improve their teaching efficiency.

Keywords: Awareness, Professionalism, Teacher Professionalism, In-service College Teachers, Teacher Effectiveness.

\section{INTRODUCTION}

At the very outset and simplistically, we, human beings, need somebody to get the various jobs done. Then there is a long list of the jobs requiring some degrees of skills and expertise to execute them. The more the societies got complex, the more emergence of institutions and organizations was seen to balance the demand and supply in both qualitative and quantitative terms. In education, the long-standing notion of everyone can teach is being replaced. A deep quest to incorporate skills, competence, and professionalism is in vogue amongst the stakeholders. Education universally has undergone extensive transformation and innovation (Hafferty \& Castellani,2010).

Whitty (2008) further extended the concept by stipulating traditional, managerial, collaborative, and democratic. Traditionally refers to as suggestive is the name, classic view of specialized knowledge, ethical code, service compulsion, autonomous practice, and culture. Managerial professionalism agrees with Sachs' concept of the business model above. The final two, namely collaborative and democratic, refer to interprofessional sharing and equity, respectively.

Menter \& Flores (2021) put forward four ages of professionalism as pre-professional, autonomous, collegial, and postprofessional, or postmodern. Thus, the professionals possess complete knowledge and skills that distinguish them from the others. This demarcation line between them and laymen bestows them with a special kind of power that they exercise in fulfilling their duties and obligations towards the client (Beaton, 2010).

Similarly, there has been a lot of debate all over the world on professionalism, describing its typology as democratic and managerial. Influenced by the former, the professionals strive for social justice through professional activities while the latter is related to business-like mode, assuming professionals to be efficient, accountable, target-oriented, and compliant. Professionalism in various professions lies in between the two extremes given above (Sachs, 2016).

Hence, in Pakistan, the situation of education holistically is the least encouraging. The teachers' professionalism was having the late beginning on both the levels, i.e., on the government side, which may be termed as professionalizing of the teachers by equipping them with the best of modern pre-requisites of teaching activity and on the teachers' side as their efforts for proving themselves as best proponents of what they are expected to fulfill. After shunning the slavery of the colonial era, the nation's history is replete with inconsistent policies. The notions of Nationalization (1972), Islamization (1979), and the aversion in the name of enlightened moderation offer just a glimpse of the disparities concerning education. The result is quite explicit from the current state of affairs that neither the system nor the teachers could access the bottom-line of quality and standards aspired by the nation (Ro, 2020). 
Hoodbhoy (2004), in the critique of the education system in Pakistan, mentioned that the teachers in Pakistan are battling alone in overcrowded classrooms with a lack of resources, training, pay, and most importantly, acknowledgment. The reason being the lack of seriousness and commitment on the part of the bureaucracy and top-down implementation process. Coupled with meager state funding, the other factors of the education system's ruination include bureau-political interference, lack of accountability, low curriculum, and assessment standards catalyzed by substandard teacher training programs (Evetts,2014).

Accordingly, teachers are responsible for teaching effectively thrust upon them in what Flores (2018) calls the preprofessional stage of their development. The expectation level on the part of parents and authorities is reaching what he calls the post-professional step. Thus, the need of the time is to have professionally committed individuals in the schools. The callous treatment with teachers made them quite indifferent to their performance (Harwood, \& Tukonic,2016).

Hence, professionalism is limited to the mechanics of skills in any profession. Still, it is an indescribable sort of entity that surpasses the routinized traits like disposition, attire, and too many more body and soul virtues. In Maxwell \& Schwimmer (2016) perspective, it is the consensus of the "norms" that may apply to being and behaving like a professional within personal, organizational, and broader political conditions.

Contrary to the ongoing discussion on the subject, Marom (2019) is among the detractors of professionalism and holds that it undermines the minority teachers. Its promotion benefits the few by causing self-centred politicizing of the professionals. Summing it up, it threatens equity, democracy, and diversity in the profession. Similarly, Knapp, Gottlieb \& Handelsman (2017) regards professionalism as the tools, rhetorical ventures, and strategies employed by occupational groups to better their working conditions, remuneration, and status.

The body of literature available so for, predominantly placed all other ingredients of professionalism on due status but ignored the important aspect of professionalism, namely the teachers' perceptions. The focus of research on professionalism has been occupied by the professional development and the factors that constitute it, with little attention towards the teachers themselves (Eryaman,2007).

Thus, this investigation aims to sift through the teachers' ideas, perceptions, and thoughts about the phenomenon of professionalism. It's justified and vital to know whether the notions they have agreements with the prevailing ones being propagated and promoted by the stakeholders to improve the quality of teaching and profession or some other snapshot occupying their mind. It would be quite essential to see if they think ample space is being given to their aspirations or the current frameworks are preoccupied with wrong assumptions of professionalism? This scenario becomes further interesting to investigate when the strict and ideal notions are being challenged, and mass proliferation of professionalism is in vogue (Sethy,2018).

Therefore, due to the increasing autonomy being certain to the educators, professionalism leftovers one of today's most essential educations attributes. So, it's necessary to know which type of attitude the teachers have about their professionalism. The current study intends to identify the professional attitude of college teachers, which reflects teachers' excellence. The quality of education is based on teachers' quality, and so the professionalism of teachers deals with quality education.

\section{OBJECTIVES OF THE STUDY}

- To assess the attitude of in-service college-level teachers regarding professionalism.

- To investigate factors that influence teachers' professionalism at the college level.

\section{REVIEW OF RELATED LITERATURE}

Little is known about the history of professions. According to Mukeredzi (2013) jobs are occupations having knowledge and skills to exercise for the public welfare (p. 12)? And according to Keddie (2017), these mandatory social services attained the form of classic professions of law, medicine, and clergy after an evolutionary process.

Sambell, Brown \& Graham (2017) in their book "The professions" mentioned five genuine or source professions: divinity, armed forces, medical, law, and education. The number again remains the same as he regards military and police as offspring of law required for its enforcement, and education is an outgrowth of divinity.

With the advent of new scholarly paradigms in every arena of life, the whole workmanship scenario has changed drastically, making it more challenging to arrive at any unanimous and agreed-upon definition of the word profession. The ruling assertions hovered around knowledge and skills. Expert knowledge, monopoly of services, and compulsory government licensing are necessary for an occupation called a profession. As there is a case with public opinion, occupational status assessment parameters tend to be blurred and ambiguous (Torres \& Weiner,2018).

Typical qualities of the profession as given by Snoek, Swennen, and Van der Klink (2009);

- Autonomy by exercising control overwork, a type of monopolistic feature of professional activities. 
- Professions have mechanisms of entry into and exclusion if members fail to comply with the standards of expertise and ethical conduct.

- Devise codes for ensuring the trust of society and the government that generally has the authority of licensing the profession and professionals.

- Professions ensure members' orientation on sound knowledge that, on the one hand, equips them with skills and grants them reasons for the monopolistic practice.

- Members of professions have self-employment and not as contracture.

Evans (2008) professions deal with almost all aspects of human life, ranging from healthy emotional and physical existence, reducing conflicts, finance, education, law, peace, art, entertainment to theology, and hereafter matters. She credits the professions making various kinds of provisions for remediation of 'risk societies.

Campbell-Barr (2018) similarly synthesizes a profession's attributes as extensive training, mandatory licensing, congenial working situations, dynamic professional association, work autonomy, handsome reward, and prestige.

Davies (2017) highlights comparatively a well-rounded definition of teachers' professionalism "Professionalism is a process more than an outcome, a way of encountering new students and new classroom problems and of finding meaning and solutions to them as you grow. It is not a "thing" acquired or worn like a piece of clothing; at no time will you have become professional once and for all.

Similarly, "Professional autonomy; a clearly defined, highly developed, specialized, and theoretical knowledge base; control of training, certification, and licensing of new entrants; self-governing and self-policing authority, especially concerning professional ethics; and a commitment to public service" are the prerequisites of a profession $(\mathrm{Ro}, 2020)$.

\section{TEACHING AS A PROFESSION}

Teachers have a long history of proclamation of professional status for themselves as well as for their profession. They blame society in general and the state in particular for not being able to deliver due privileges and responsibilities for teaching to acclaim the complete status. During the past century, teachers reiterated their professional claim on the complexity of services they render that requires knowledge and skills. Still, their stance has been a bit vague (Price \& Weatherby,2018).

Pearson \& Moomaw (2005) believes that the so for presented models that swelled the debate of status for professions have resulted in no. As the prescribed criteria and attributes are ill-defined and practically unachievable, make it necessary to devise a realistic set for judging the teaching against in the 21st century. Moving on further, Newlyn (2014) synthesized the following benchmarks for teaching to be called a profession:

1. Existence of an autonomous governing entity.

2. Behavior originating from the bulk of knowledge with continuous efforts to refine it (p.537).

Although teachers generally have many achievements on their backs, teaching historically has never been accounted for as a true profession despite their claim of being professionals.

Ingersoll, Merrill \& May (2011) tried to shape up the debate of teaching as a profession on an empirical and theoretical basis. Diverting from the narratives of exploration and evaluation, history, and normative description, they proclaim analytical and descriptive stance as

From the above-claimed data, they evolved the following indicators to judge teaching.

- Qualification and certifying levels

- Orientation and mentoring programs for prospective teachers

- Provision of support, prospects, and participation

- Access and authority in the decision process

- Reward levels

- Esteem and work-related community standing (p.186).

However, the issue has been a contested one as "Teaching constitutes a type of profession fundamentally different from those that receive the greatest public recognition: that in fact, teachers belong to a distinctive class" (Goodwin,2021).

\section{Teachers' Professionalism}

Whatever definition, traits, or characteristics we connote with the profession, teachers are persistent with their claim of professionalism. The issue is not to be settled with their self-centred lawsuit. However, they need recognition from society, which seems still a far cry as we see an abundance of literature related to teacher professionalism in books, 
conferences, and seminars. "Teacher unions, administration, and teachers themselves are trying to convince society that teachers are indeed part of a true profession. Having society recognize teachers as professionals are essential to acquiring all the other characteristics that are attributed to being part of a true profession (Guskey,2002).

Tatto (2021) based the professionalism of teachers on moral dynamics. According to which professionalism is the demeanor of individuals within the profession and a way of treating clients, utilization of skills in a collegial context

Noordegraaf (2007) expressing views about teacher professionalism from in reforms perspective, contends that proponents of the profession regard reform as de-professionalization. The reforms align them with reprofessionalization, arguing that reforms are equipping teachers with expertise befitting the requirements of modern society.

Accordingly, the aspects of remuneration, status, autonomous practice, and respect for teachers, which often occupy the central place in teacher professionalism, are essential for engaging the talented people in teaching but not the primary motives for the pursuance of professionalism in education (Mayer \& Mills,2021).

Rizvi \& Elliot (2005) studied teachers' perceptions towards professionalism in Pakistan, with specific relation to the factors like teacher efficiency, practice, collaboration, and leadership. Their findings suggested that, unlike prevailing thought, teachers perceive professionals for them and expect the success of their teaching process (p.48).

Freidson (2001) surveys teachers' professionalism in the English context with particular reference to reforms. As the trends of centrality and marketization, the involvement of various stakeholders symbolizes a period of significant change for teaching professionals (p.1).

Making a point of reference, there have been four teaching professionalism phases as many the reforms.

- Uninformed professionalism- the period of ripe autonomy but deficient knowledge appropriateness, skills, and necessary attitudes for society in transformation.

- Uninformed prescription- the phase with hallmarks of things externally imposed for political instead of educational motives.

- Informed prescription- a continuation of the above, but an empirical rationale was backing it up. And finally,

- Informed professionalism- when teachers are appropriately equipped with the knowledge base, skills, and attitudes and deserve the state's licensed autonomy (Barber, Odean \& Zheng, 2005).

Tichenor \& Tichenor (2009) compared the teacher and administrator perspectives on multiple dimensions of professionalism. They divided the dimensions into four categories: personal characteristics, commitment to change and continuous improvement, and participation in educational activities beyond the classroom's confines (p.16). The optimum consonance between teachers and administrators was found on two dimensions 1) Personal Character and 2) Subject and Pedagogical Knowledge, as these are entering behaviors that are carried through the whole career. However, there was a considerable difference in Commitment to Change/ Continuous Improvement and Beyond the Classroom dimensions of professionalism (p.17).

Hargreaves (2000), acknowledging the transitory nature of teacher professionalism, discussed the development in the field under four ages, stating that these may not be universal but common among the developing countries with shuffling order (p.153).

The four ages include:

- The pre-professional age was the age of simple teaching. Although there were demands on the part of administrators, they revolved around common sense. The lecture method was primarily used, and few students conversed with the teachers on behalf of the whole class. Teacher preparation was founded in theoretical and philosophical endeavours, while teachers got practicalities through apprenticeship and trial and error (p.156).

- The age of professional autonomy-this age symbolized the significant improvement regarding the status and standing of teaching. Autonomy was the salient feature of this age. However, exaggerated than actual but helped the cause as teachers are the best of the stakeholders to opt for the best and reasonable practices for the pupils' more considerable benefits (p.157).

- The age of the collegial professional-the previous age of autonomy and individuality was short of coping with the fresh challenges of complexities of classroom practices, knowledge explosion, and mainstreaming of children with special needs (p.163).

- The post-professional age- is marked by two dominant advancements of economics and communications, the former captured by global corporate powers and the policies being market-oriented. Simultaneously, the latter has given vent to shrunken distances and knowledge explosion with severe assault on professionalism (p.167). Now they are to 
battle with docked salaries, media trials, and political agendas that require their return to collegial professionalism (p.170).

Teachers aspire to utilize their skills cum knowledge for the pupils' needed satiation while bureaucracy expects directional regulation compliance. Thus, it becomes the crossroads situation among conformity and autonomy, shared decisions and managerialism, collegiality, and isolation (Wardoyo \& Herdiani,2017).

This study is based on the research paradigm of positivism and was a quantitative study. The conceptual framework for this study shows that the professionalism of teachers was considered an independent variable and that the awareness of teachers related to professionalism worked as a dependent variable. This study explains how the factors of professionalism (classroom management, the effectiveness of teachers, teaching methodology, and professional development of teachers) influence college teachers' awareness regarding professionalism.

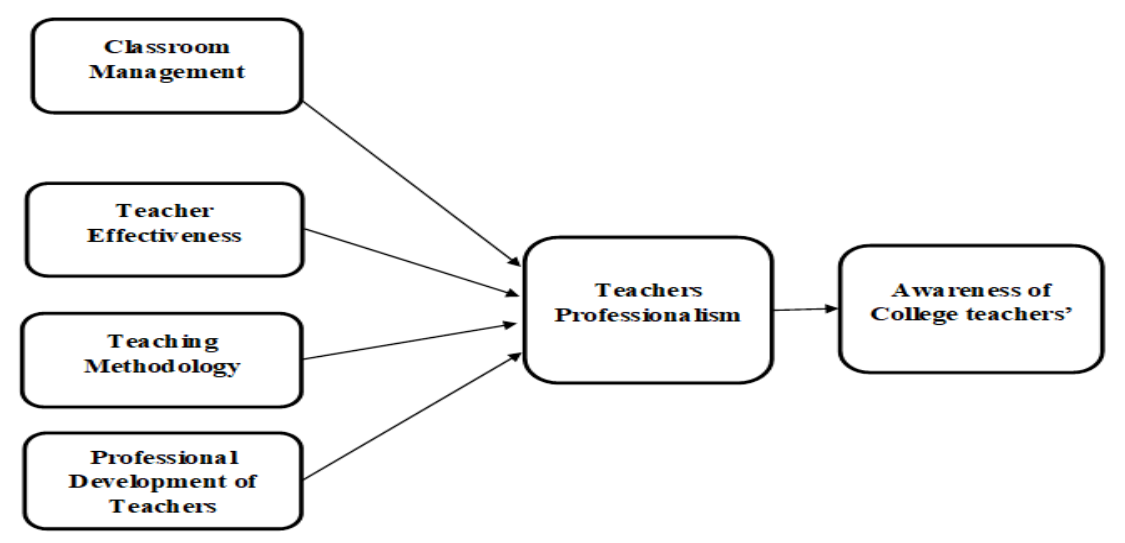

Figure 1: A conceptual framework of the study by author

\section{RESEARCH HYPOTHESIS:}

$\mathbf{H o}_{1:}$ There is no significant difference between the response of male and female participants.

$\mathbf{H o}_{2}$ : There is no significant difference between married and unmarried participants.

Ho $_{3}$ : There is no significant difference between the permanent participants and on contract participants.

Ho$_{4}$ : There is no significant difference among the response of respondents that belong to different age groups.

$\mathbf{H o}_{5}$ : There is no significant difference among the response of participants with different teaching experiences.

Ho$_{6}$ : There is no significant difference among the response of participants with having different qualifications.

$\mathbf{H o}_{7}$ : There is no significant difference among the response of respondents that belong to the different designation.

\section{RESEARCH METHODOLOGY}

This study was undertaken to find out the awareness of in-service College teachers regarding professionalism. This research study's nature was descriptive, and a survey design was used to conduct this study. Quantitative data analysis has been done with the help of SPSS version 23.

\section{Population and Sample}

Target respondents of the study were public sector college teachers of Punjab. This study was conducted to gain an understanding of professionalism among college teachers in the Multan district. The researcher utilized a simple random sampling technique to draw a sample. 11 male colleges and 9 female colleges were selected. So the data was collected from 239 female and male 101 college teachers by using a questionnaire.

\section{Instrument development}

The questionnaire was utilized to collect data from respondents by employing a 5-point Likert scale. The research tool had four parts. The first part was related to classroom management (F1), the second part was teaching effectiveness (F2), the third part was teaching methodology (F3), and the last part was related to the professional development of teachers (F4). To examine the validity of the research instrument (questionnaire) for the study, the researcher got help from a panel of experts to identify the questionnaire's stability and faults and improve the tool. The researcher also ensures the tool's reliability with the help of SPSS by using Cronbach's alpha. The value of the reliability coefficient was 0.83 .

Table 1: Reliability of Scales (Factors)

\begin{tabular}{llcc}
\hline & Factors & Items & $\boldsymbol{\alpha}$ value \\
\hline F1 & Classroom Management & 14 & 0.73 \\
\hline
\end{tabular}




\begin{tabular}{llll}
\hline F2 & Teacher Effectiveness & 09 & 0.81 \\
\hline F3 & Teaching methodology & 10 & 0.89 \\
\hline F4 & Professional Development of teachers & 13 & 0.77 \\
\hline
\end{tabular}

The table shows the internal consistency among items of the scale. The alpha values for factors were Classroom Management 0.73, Teacher Effectiveness 0.81, Teaching methodology 0.89, and Professional Development of teachers, 0.77 , significant and acceptable in statistics. Therefore, it is concluded that the instrument was reliable for the research.

\section{Data Collection and Data Analysis}

The tool used to collect data from participants was the survey. In evaluating the collected data from respondents, descriptive statistics and inferential statics were used. The researcher picked mean, frequency, and percentage for descriptive statistics and used z-test and one-way ANOVA for inferential statistics.

\section{RESULTS OF THE STUDY}

Table 2: Descriptive Analysis of demographic variables

\begin{tabular}{lll}
\hline Gender & Frequency & Percentage \\
\hline Male & 101 & $30 \%$ \\
\hline Female & 239 & $70 \%$ \\
\hline Area & & \\
\hline Rural & 299 & $88 \%$ \\
\hline Urban & 41 & $12 \%$ \\
\hline Marital status & & \\
\hline Married & 222 & $65 \%$ \\
\hline Unmarried & 118 & $35 \%$ \\
\hline Age & & \\
\hline $20-30$ & 141 & $42 \%$ \\
\hline $31-40$ & 140 & $41 \%$ \\
\hline $41-50$ & 59 & $17 \%$ \\
\hline Teaching experience (Years) & & \\
\hline $0-5$ & 147 & $43 \%$ \\
\hline $6-10$ & 145 & $42 \%$ \\
\hline $11-15$ & 48 & $15 \%$ \\
\hline Qualification & & \\
\hline M.A/M.sc & 153 & $45 \%$ \\
\hline M.Phil./MS & 171 & $50 \%$ \\
\hline P.hd & 16 & $5 \%$ \\
\hline Designation & 177 & $52 \%$ \\
\hline Lecturer & 142 & $42 \%$ \\
\hline Assistant Professor & 21 & $6 \%$ \\
\hline Associate professor & & \\
\hline Nature of employment & & \\
\hline Permanent & & \\
\hline Contract & & \\
\hline & & \\
\hline
\end{tabular}

Ratio of rural was more (rural $88 \%, n=i s$ 299) than the urban area (urban 12\%, $n=41$ ), groups (20-30), (30 -40), (41-50) are divided but most of them belongs to $(20-30,42 \%, n=141)$ age group. Table also display ratio of female is more (female $70 \%, \mathrm{n}=239)$ than male $(30 \%, \mathrm{n}=101)$ and ratio of married persons is more (married $65 \% \mathrm{n}=222)$ than unmarried (unmarried 35\%, $\mathrm{n}=35)$. Teaching experience divided in three groups (0-5), (6-10), (1-15) but most of them belongs to $(0-5,43 \%, \mathrm{n}=147)$ group and qualification of teachers divided in M. A/M.sc, M.Phil./MS, Ph.D and most of them belongs to M.Phil./MS (50\%,n=171) more than the (M.A/M.sc 45\%,n=153), Ph.D(5\%,n=16). Designation of college teachers is categorized in lecturer, assistant professor \& associate professor and most of them belongs to lecturer (52\%, $\mathrm{n}=177)$ more than assistant professor $(42 \%, \mathrm{n}=142)$ and associate professor $(6 \% \mathrm{n}=21)$. Table also display ratio of permanent college teachers (permanent 63\%, $n=214)$ more than teachers who were on contract $(37 \%, n=126)$.

Table 3: Descriptive Statistics of Classroom Management Factor

\begin{tabular}{|c|c|c|c|c|c|c|c|c|c|c|c|}
\hline \multirow{2}{*}{ Statements } & \multicolumn{2}{|c|}{ Frequently } & \multicolumn{2}{|c|}{ Fairly often } & \multicolumn{2}{|c|}{ Sometimes } & \multicolumn{2}{|c|}{ Rarely } & \multicolumn{2}{|c|}{ Not at all } & \multirow[t]{2}{*}{ Mean } \\
\hline & $\mathbf{F}$ & $\%$ & $\mathbf{F}$ & $\%$ & $\mathbf{F}$ & $\%$ & $\mathbf{F}$ & $\%$ & $\mathbf{F}$ & $\%$ & \\
\hline $\begin{array}{l}\text { You promote an atmosphere of equality in your } \\
\text { classroom. }\end{array}$ & 139 & 41 & 40 & 12 & 86 & 25 & 71 & 21 & 4 & 1 & 3.70 \\
\hline You encourage students to ask questions in the & 118 & 35 & 52 & 15 & 85 & 25 & 82 & 24 & 3 & 1 & 3.59 \\
\hline
\end{tabular}


class.

\begin{tabular}{lllllllllllllll}
\hline You develop and practise classroom & 92 & 27 & 73 & 21 & 74 & 22 & 98 & 29 & 3 & 1 & 3.45
\end{tabular} management and discipline plan.

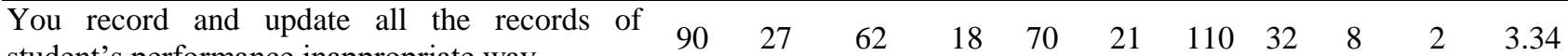

student's performance inappropriate way.

You appreciate students for their excellent

performance.

$\begin{array}{lllllllllll}95 & 27 & 64 & 19 & 111 & 33 & 67 & 20 & 3 & 1 & 3.54\end{array}$

You create a positive classroom climate that is

socially, emotionally, and physically safe for $\begin{array}{llllllllllll}39 & 30 & 46 & 15 & 145 & 30 & 104 & 23 & 6 & 2 & \mathbf{2 . 5 0}\end{array}$

students.

You accept feedback from your students in a

positive way.

$\begin{array}{lllllllllll}48 & 14 & 82 & 24 & 88 & 26 & 105 & 31 & 17 & 5 & 3.11\end{array}$

\begin{tabular}{l}
$\begin{array}{l}\text { You have a clear understanding of your lesson } \\
\text { goals. }\end{array}$ \\
\hline
\end{tabular}

\begin{tabular}{lllllllllllll}
\hline You use civilized language in your classroom. & 86 & 26 & 74 & 22 & 84 & 25 & 91 & 27 & 5 & 1 & 3.43 \\
\hline
\end{tabular}

You attend your classes regularly.

\begin{tabular}{lllllllllllll}
\hline You ensure that all the students receive the equal & 31 & 9 & 116 & 34 & 111 & 33 & 78 & 23 & 4 & 1 & 3.27
\end{tabular}

opportunity of progress

You employ proper management strategies to maintain classroom discipline.

$\begin{array}{lllllllllll}46 & 14 & 79 & 23 & 115 & 34 & 91 & 27 & 9 & 3 & 3.18\end{array}$

You create a productive learning climate through participation in college activities.

\begin{tabular}{lllllllllll}
83 & 24 & 64 & 19 & 103 & 30 & 84 & 25 & 6 & 2 & 3.39 \\
\hline 56 & 17 & 73 & 22 & 135 & 40 & 76 & 22 & 2 & 1 & 3.51
\end{tabular}

you maintain a learning community in which student assume responsibility

Participants have a positive attitude towards classroom management in assessing awareness among participants about professionalism. Still, they disagreed that they create a positive classroom climate that was socially, emotionally, and physically safe for their students. They have a lack of clear understanding of their lesson goals.

Table 4: Descriptive Statistics of teacher Effectiveness Factor

\begin{tabular}{|c|c|c|c|c|c|c|c|c|c|c|c|}
\hline \multirow[t]{2}{*}{ Statements } & \multicolumn{2}{|c|}{ Frequently } & \multicolumn{2}{|c|}{$\begin{array}{c}\text { Fairly } \\
\text { often }\end{array}$} & \multicolumn{2}{|c|}{ Sometimes } & \multicolumn{2}{|c|}{ Rarely } & \multicolumn{2}{|c|}{$\begin{array}{c}\text { Not at } \\
\text { all }\end{array}$} & \multirow[t]{2}{*}{ Mean } \\
\hline & $\mathbf{F}$ & $\%$ & $\mathbf{F}$ & $\%$ & $\mathbf{F}$ & $\%$ & $\mathbf{F}$ & $\%$ & $\mathbf{F}$ & $\%$ & \\
\hline You dress professionally at your workplace. & 59 & 17 & 98 & 29 & 122 & 36 & 47 & 14 & 14 & 4 & 3.41 \\
\hline You complete your work on time. & 46 & 14 & 101 & 30 & 125 & 37 & 67 & 20 & 2 & 1 & 3.36 \\
\hline $\begin{array}{l}\begin{array}{l}\text { You follow the rules and regulations of your } \\
\text { institution. }\end{array} \\
\end{array}$ & 40 & 12 & 97 & 29 & 135 & 40 & 56 & 17 & 12 & 3 & 3.29 \\
\hline You utilize instructional time effectively. & 41 & 12 & 90 & 27 & 122 & 36 & 79 & 23 & 8 & 2 & 3.23 \\
\hline $\begin{array}{l}\text { You promote creative and critical thinking among } \\
\text { students. }\end{array}$ & 39 & 11 & 115 & 34 & 90 & 27 & 86 & 25 & 10 & 3 & 3.26 \\
\hline $\begin{array}{l}\text { You create a learning community in which individuals } \\
\text { and their opinion are respected. }\end{array}$ & 42 & 12 & 113 & 33 & 120 & 36 & 60 & 17 & 5 & 2 & 3.37 \\
\hline $\begin{array}{l}\text { You consider testing students' previous knowledge as a } \\
\text { part of your lecture. }\end{array}$ & 7 & 11 & 89 & 26 & 140 & 41 & 66 & 19 & 8 & 3 & 3.24 \\
\hline $\begin{array}{l}\text { You utilize appropriate tools of inquiry according to } \\
\text { the nature of the subject. }\end{array}$ & 25 & 7 & 97 & 28 & 139 & 41 & 65 & 19 & 14 & 4 & 3.16 \\
\hline $\begin{array}{c}\text { Your teaching promotes self-reflection among students. } \\
\text {. }\end{array}$ & 37 & 11 & 18 & 5 & 88 & 26 & 115 & 34 & 82 & 24 & 2.93 \\
\hline
\end{tabular}

Participants had a positive attitude towards the teacher effectiveness factor in evaluating knowledge among participants about professionalism but did not accept that their teaching did not promote self-reflection among their students.

Table 5: Descriptive Statistics of teaching methodology Factor

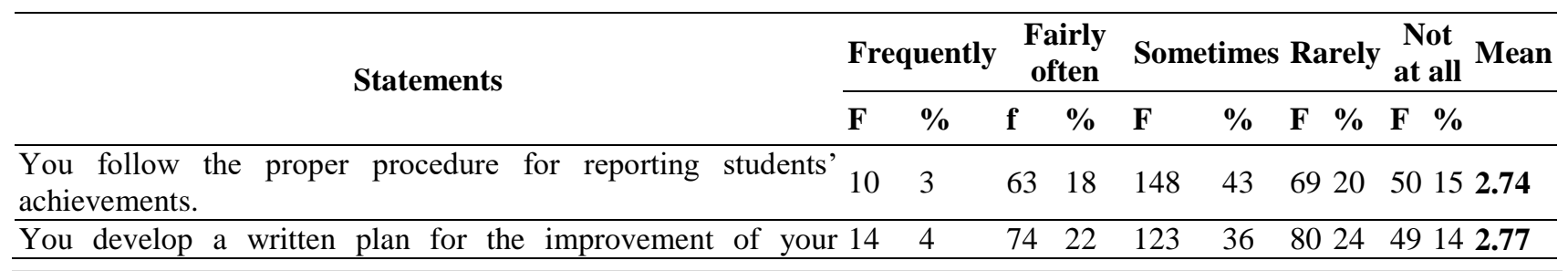


teaching.

\begin{tabular}{lllllllllll}
\hline You have complete command over your subject content. & 10 & 3 & 82 & 24 & 123 & 36 & 73 & 22 & 27 & 3.07 \\
\hline
\end{tabular}

\begin{tabular}{lllllllllll}
\hline You motivate students to solve their problems themselves. & 77 & 23 & 11132 & 71 & 21 & 38 & 11 & 4313 & 3.41
\end{tabular}

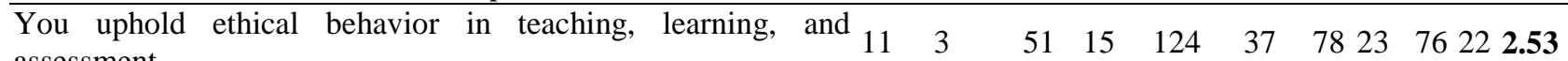

assessment.

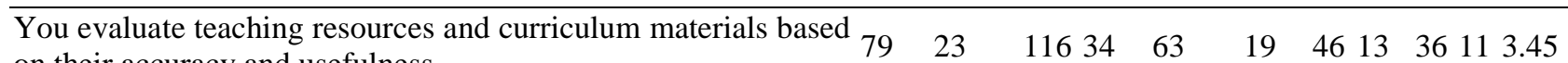

on their accuracy and usefulness.

$\begin{array}{lllllllllll}23 & 116 & 34 & 63 & 19 & 46 & 13 & 36 & 11 & 3.45\end{array}$

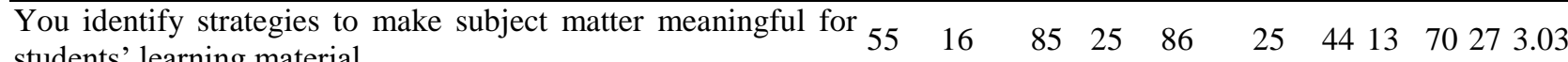

students' learning material.

\begin{tabular}{llllllll}
\hline You encourage students to pursue the with interest. & 72 & 21 & 11835 & 71 & 21 & 3811 & 41123.41 \\
\hline
\end{tabular}

You develop effective lessons by organizing instructional $102 \quad 30 \quad 86 \quad 25 \quad 59 \quad 17 \quad 4914 \quad 44133.45$ activities and materials intelligently.

You explain the content to the students in multiple ways.

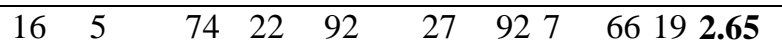

Participants had a positive attitude towards the teaching methodology factor in evaluating knowledge among participants about professionalism. Still, they disagree that they follow the proper procedure for reporting their students' achievement, and they did not develop a written plan for improvement of their teaching. They also showed a negative attitude towards the statements explaining the content to the students in multiple ways and uphold ethical behavior in their education, learning, and assessment.

Table 6: Descriptive Statistics of professional development of teachers Factor

\begin{tabular}{|c|c|c|c|c|c|c|c|c|c|c|}
\hline \multirow[t]{2}{*}{ Statements } & \multicolumn{2}{|c|}{ Frequently } & \multicolumn{2}{|c|}{$\begin{array}{c}\text { Fairly } \\
\text { often }\end{array}$} & \multicolumn{6}{|c|}{ Sometimes Rarely Not at all Mean } \\
\hline & $\mathbf{F}$ & $\%$ & $\mathbf{f}$ & $\%$ & $\mathbf{F}$ & $\%$ & $\mathbf{F}$ & $\%$ & $\mathbf{F}$ & $\%$ \\
\hline $\begin{array}{l}\text { You seek guidance from other professionals to improve } \\
\text { your teaching skills. }\end{array}$ & 8 & 2 & 78 & 23 & 119 & 35 & 58 & 17 & 77 & 232 \\
\hline $\begin{array}{l}\text { You attend professional development programs to } \\
\text { enhance your professional skills. }\end{array}$ & 93 & 27 & 74 & 21 & 107 & 31 & 47 & 14 & 19 & 53.4 \\
\hline $\begin{array}{l}\text { You attend all relevant professional development } \\
\text { programs. }\end{array}$ & 13 & 4 & 56 & 16 & 100 & 30 & 90 & 26 & 81 & 240 \\
\hline $\begin{array}{l}\text { You encourage learners to value and practice ethical } \\
\text { and Islamic values in life. }\end{array}$ & 68 & 20 & 62 & 18 & 124 & 36 & 77 & 23 & 9 & 33. \\
\hline You create a safe and secure learning environment. & 47 & 14 & 77 & 22 & 129 & 38 & 81 & 24 & 6 & 23.7 \\
\hline $\begin{array}{l}\text { You collaborate with your colleagues to develop } \\
\text { teaching skills. }\end{array}$ & 12 & 3 & 70 & 21 & 107 & 31 & 100 & 30 & 51 & 152.6 \\
\hline $\begin{array}{l}\text { You develop and administer self-assessment, } \\
\text { measurement. }\end{array}$ & & 2 & 60 & 18 & 140 & 41 & 65 & 19 & 68 & 202.6 \\
\hline You feel that you need to improve your teaching skills. & 11 & 3 & 57 & 17 & 126 & 37 & 64 & 19 & 82 & 242.56 \\
\hline You are emotionally attached to your profession. & 89 & 26 & 53 & 16 & 88 & 26 & 72 & 21 & 38 & 113.2 \\
\hline $\begin{array}{l}\text { You develop and practice classroom management and } \\
\text { discipline plan. }\end{array}$ & 10 & 3 & 57 & 17 & 112 & 33 & 103 & 30 & 58 & 172.5 \\
\hline $\begin{array}{l}\text { You develop a continuous internal evaluation of } \\
\text { students' performance and skills at different stages of } \\
\text { the academic program. }\end{array}$ & 39 & 11 & 34 & 10 & 140 & 41 & 69 & 20 & 58 & \\
\hline
\end{tabular}
\begin{tabular}{llllllllllllll}
\hline You are ready to improve your basic teaching & 20 & 6 & 43 & 13 & 122 & 35 & 93 & 27 & 62 & 18 & $\mathbf{2 . 6 0}$
\end{tabular} techniques.

\begin{tabular}{lllllllllll}
\hline You use reflective practice in your classes. & 33 & 10 & 48 & 14 & 130 & 38 & 65 & 19 & 64 & 19 \\
\hline
\end{tabular}

Participants had a positive attitude towards the professional development of teachers' factor in evaluating knowledge among participants about professionalism. Still, they disagreed that they sought guidance from other professionals to improve their teaching skills and did not attend all relevant professional development programs. They also showed a negative attitude towards the statements that they did not develop a continuous internal evaluation of their student's performance and skills at different academic program stages, not ready to improve their basic teaching techniques, and did not utilize their reflective practice in their classes. They did not collaborate with their colleagues to develop their teaching skills, they did not develop and practice classroom management and discipline plan, and did not develop and self-assessment, measurement system.

Table 7: Inter Correlations between Factors (Factor matrix)

\begin{tabular}{llllll}
\hline & & F1 & F2 & F3 & F4 \\
\hline \multirow{2}{*}{ F1 } & Pearson Correlation & 1 & $.479^{* *}$ & $.357^{* *}$ & $.445^{* *}$ \\
\cline { 2 - 6 } & Sig. (2-tailed) & & .000 & .000 & .000 \\
\hline
\end{tabular}




\begin{tabular}{clllll}
\hline \multirow{2}{*}{ F2 } & $\mathrm{N}$ & 340 & 339 & 340 & 340 \\
\cline { 2 - 6 } & Pearson Correlation & $.479^{* *}$ & 1 & $.502^{* *}$ & $.461^{* *}$ \\
\cline { 2 - 6 } & Sig. (2-tailed) & .000 & & .000 & .000 \\
\cline { 2 - 6 } & $\mathrm{N}$ & 339 & 339 & 339 & 339 \\
\hline \multirow{2}{*}{ F3 } & Pearson Correlation & $.357^{* *}$ & $.502^{* *}$ & 1 & $.680^{* *}$ \\
\cline { 2 - 6 } & Sig. (2-tailed) & .000 & .000 & .000 \\
\cline { 2 - 6 } & $\mathrm{N}$ & 340 & 339 & 340 & 340 \\
\hline F4 & Pearson Correlation & $.445^{* *}$ & $.461^{* *}$ & $.680^{* *}$ & 1 \\
\cline { 2 - 6 } & Sig. (2-tailed) & .000 & .000 & .000 \\
\cline { 2 - 6 } & N & 340 & 339 & 340 & 340 \\
\hline$* *$. & Correlation is significant at the 0.01 level (2-tailed).
\end{tabular}

All four variables of perceived professionalism have a statistically significant linear relationship $(\mathrm{p}<.001)$. The direction of the relationship is positive (i.e., all four variables are positively correlated), range of correlations among factors was 0.36 to 0.68 . The association's strength was a high between F3 (teaching methodology) and F4 (professional development), while the strength is approximately moderate for all other pairs.

Table 8: Significance of difference between factor (Area, Gender, and nature of employment)

\begin{tabular}{lllll}
\hline Marital status & N & Mean & S.D & z-value \\
\hline Married & 222 & 45.5566 & 6.25247 & \multirow{2}{*}{1.676} \\
\hline Un-married & 118 & 44.3983 & 5.68420 & \\
\hline Nature of employment & N & Mean & S.D & z-value \\
\hline Permanent & 214 & 44.952 & 6.13265 & \multirow{2}{*}{0.794} \\
\hline Contract & 126 & 45.4683 & 6.0222 & \\
\hline Gender & N & Mean & S.D & z-value \\
\hline Female & 239 & 44.97 & 6.36 & \multirow{2}{*}{1.67} \\
\hline Male & 101 & 45.49 & 5.37 & \\
\hline
\end{tabular}

Table displays that the calculated values were less than the table values at a 0.05(1.96) level of significance, showing an insignificant difference in performance between permanent and contracted participants, married and unmarried, and male and female participants.

Table 9: Significance of the difference between factors (age, teaching experience, teachers 'qualification, and designation)

\begin{tabular}{|c|c|c|c|c|c|}
\hline \multicolumn{6}{|l|}{ ANOVA } \\
\hline & & Sum of & Df & Mean Square F & Sig. \\
\hline \multirow{3}{*}{ Age } & Between Groups & 102.473 & 71 & 1.443 & 4.960 .365 \\
\hline & Within Groups & 77.693 & 267 & .291 & \\
\hline & Total & 180.165 & 338 & & \\
\hline \multirow{3}{*}{$\begin{array}{l}\text { Teaching } \\
\text { Experience }\end{array}$} & Between Groups & 92.255 & 71 & 1.299 & 4.699 .002 \\
\hline & Within Groups & 73.834 & 267 & .277 & \\
\hline & Total & 166.088 & 338 & & \\
\hline \multirow{3}{*}{ Qualifications } & Between Groups & 65.073 & 71 & .917 & 5.039 .442 \\
\hline & Within Groups & 48.561 & 267 & .182 & \\
\hline & Total & 113.634 & 338 & & \\
\hline \multirow{3}{*}{ Designation } & Between Groups & 80.851 & 71 & 1.139 & 6.715 .003 \\
\hline & Within Groups & 45.279 & 267 & .170 & \\
\hline & Total & 126.130 & 338 & & \\
\hline
\end{tabular}

The result of ANOVA display that there is a significant difference among the performance of college teachers that had different teaching experience and belong to different designation because the value of $\mathrm{p}$ is smaller $0.05(\mathrm{p}<0.05)$ and there is an insignificant difference among the performance of college teachers that belong to different age groups and having different qualification.

\section{DISCUSSION}

As time changes the roles and the responsibilities of the teachers also changed. Teacher's view towards professionalism is different in every era and it is assessed in the present study as "Assessing awareness level of in-service college teachers regarding professionalism. Conclusion drawn from the main findings of the study revealed that the teachers professionally manage and promote an environment where every student is treated equally and in a disciplined way. The study of Malm (2009) supported the findings of the present work in a way that the teachers kept records of their 
student's performance and update these records for the improvements in their student's performances in the future. A professional and civilized language is used with the students and other staff of the school and the in-service college teachers also kept in view the professional dress code. Decent dress codes the identity of the teachers so the students make them role models and follow them fully when they are in any of the social setups. Teaching and the learning process and its quality is the identity of any nation and the students represent the culture of their country when they move outside of their social setup. The professionalism of teachers enables the students to make a positive view of teaching and learning and the whole system of their country's education.

Therefore, the teachers took their classes on time and they always follow rules and regulations that might be considered a necessary part of their institution. Teacher's professionalism is seen when they deliver their lessons, deal with their students and other staff, and the way they followed the institution's rules and regulations to maintain discipline in the classroom. As the study of Creasy (2015) supported the findings in a way that the teacher's professionalism is more considered when they use the available resources to deliver their lessons and to develop the evaluation tools for their students. Teachers professionally evaluate their student's progress without any biasness and he /she would be responsible for the results of his /her students. The moral development and the character-building is the main and significant feature of the teaching and learning process and it is the major responsibility of the teachers to make their students morally strong. Mostly, the moral development activities are performed by the teachers in the classroom by the teachers and the students practice them outside of the classroom when they are in the social circle.

Moreover, the present study also concluded that the teachers promote the atmosphere of learning where the opinions and the suggestions from the students are considered important and they are respected individually without any biasness. As the study of Tichenor and Tichenor (2009) supported the findings of the present study in a way that the students are respected by the teachers are their opinions regarding their learning are considered more valuable so that the students feel confident and share their thoughts with the teachers and with their peers to make changes in their learning process. Mostly, the teachers allow their students to make decisions about their learning and solve their problems by their own selves. Teachers enable the students to make decisions and think critically on their problems and solve them logically.

Accordingly, Colmer (2017) believed that the concept of professionalism in the teaching process brings changes in the system of education as a new paradigm. The present study concluded it in a way that the teachers make their teaching and learning process organized and they use valuable comments for the students when they provide feedback on the teaching methods and the lessons in the classroom and their feedback is motivated and encouraged by the teachers professionally. Students think beyond the books and invent new ways of learning and explore the world in their own way. The professional attitude of teachers towards the teaching and learning process directly positively affects the systems of education. In the modern era of technology, professionalism makes the teachers and the students more competitive and helps them to cope with the challenges of the modern world. Civilized and the mannerly behavior of the teachers towards the students makes them more respectful and significant components of the education system. Advancements in the system of education make the teacher's attitude more professional towards their teaching skills. Likewise, the needs of the students also change as the world moving towards technology day by day.

To some extent, the lack of resources and lack of availability of necessary equipment for the practical work may cause some anxiety and confusion in the teachers about how to deal with this situation. But they tackle the situations wisely and make the teaching and learning process moving forward within limited resources. Resource management is the basic feature of quality teaching where the teachers move forward the education system within few resources and make it sure the availability of those resources to the students individually and to the full extent.

So, the conclusion and major findings of the present study showed that at the college level the teachers are mostly aware of their professionalism and they perform their duties professionally rather they are in class or outside of the classroom. They promote the learning environment and motivate their students to do better in the future. Positive and active participation of the students inside and outside of the classroom is also encouraged by the teachers. Biasness in the assessment and the evaluation procedures is demotivated. All of the students are treated equally and provide equal chances of learning to them. Somehow, the environment of enthusiasm is also motivated where the students help each other without any negative intentions and help to make each other more successful. In the modern age, the teachers are fully attentive and focused towards their roles and the duties. The education system also ensures the quality education where equal chances are given to students individually.

\section{CONCLUSION}

This study concluded that teachers promote equality and imply classroom management discipline plans in their classrooms. They encourage their students to pursue their interests and ask questions in their classroom. Study participants record and update all the records of student's performance appropriately for their excellent performance, and they use civilized language in their classroom and dress professionally in their workplace. Teachers maintain a learning community where students assume responsibility and ensure that all the students receive an equal opportunity for progress, create a learning community where individuals and their opinions are respected, attend their classes regularly, and follow the rules \& regulations of their institution. Teachers utilize instructional time effectively to complete their work on time in classrooms, understand lesson goals, and evaluate teaching resources and curriculum materials based on 
their accuracy and usefulness. They consider students' previous knowledge as a part of their lecture and develop practical lessons by organizing instructional activities and materials intelligently and explaining them in multiple ways. Teachers utilize appropriate inquiry tools according to the nature of the subject and identify strategies to make subject matter meaningful for students' learning material and have full command over subject content and follow proper procedures for reporting students' achievement. Thus, this study concludes that despite various issues that prevail in teachers' professionalism and it is still a significant factor in teachers' efficiency. There are major four factors that affect teachers' professionalism (classroom management, teaching effectiveness, teaching methodology, and professional development of teachers). Teachers showed a positive attitude on these factors related to professionalism. It is further concluded that teachers should participate in various professional development activities to improve their performance and teaching skills and promote self-reflection among students and motivate them to solve their problems themselves.

\section{RECOMMENDATIONS}

- Teachers should have subject mastery in their relevant fields and prepare written plans for their improvement.

- Teachers should have a clear understanding of their lesson goals and assessment procedure.

- Teachers should follow ethical behavior in their classrooms to improve the teaching and learning process and should follow the proper procedure of reporting their student achievement.

- Teachers should employ various teaching strategies, and should adopt the reflective practices to obtain better results for their students.

- Teachers should participate in various professional development activities to improve their performance and teaching skills.

- Teachers should craft a safe and secure learning environment for their students and encourage them to follow Islamic values and ethics in their lives.

- The teacher should develop cooperation with their colleagues for the progress of the institution.

\section{LIMITATIONS}

The teachers of public sector colleges participated more frequently in this study. The personnel of private sectors was reluctant to respond to the questionnaire during data collection.

\section{AUTHORS' CONTRIBUTION}

Amna Saleem is the sole author of the research. She generates the theme of the study, conducts all the steps from introduction to conclusion. She generated hyperlinks of citations with references.

\section{REFERENCES}

1. Barber, B. M., Odean, T., \& Zheng, L. (2005). Out of sight, out of mind: The effects of expenses on mutual fund flows. The Journal of Business, 78(6), 2095-2120. https://doi.org/10.1086/497042

2. Beaton, G. R. (2010). Why professionalism is still relevant. U of Melbourne Legal Studies Research Paper, (445). https://doi.org/10.2139/ssrn.1545509

3. Campbell-Barr, V. (2018). The silencing of the knowledge-base in early childhood education and care professionalism. International Journal of Early Years Education, 26(1), 75-89. https://doi.org/10.1080/096697 60.2017.1414689

4. Colmer, K. (2017). Collaborative professional learning: Contributing to the growth of leadership, professional identity and professionalism. European Early Childhood Education Research Journal, 25(3), 436-449. https://doi.org/10.1080/1350293X.2017.1308167

5. Creasy, K. L. (2015). Defining Professionalism in Teacher Education Programs. Online Submission, 2(2), 2325.

6. Davies, R. (2017). Ethics and professionalism. In Paradoxes in Education (pp. 93-110). SensePublishers, Rotterdam. https://doi.org/10.1007/978-94-6351-185-8_6

7. Eryaman, M. Y. (2007). From Reflective Practice to Practical Wisdom: Toward a Post-Foundational Teacher Education. International Journal of Progressive Education, 3(1), n1.

8. Evans, L. (2008). Professionalism, professionality and the development of education professionals. British journal of educational studies, 56(1), 20-38. https://doi.org/10.1111/j.1467-8527.2007.00392.x

9. Evetts, J. (2014). The concept of professionalism: Professional work, professional practice and learning. In International handbook of research in professional and practice-based learning (pp. 29-56). Springer, Dordrecht.Falmer). https://doi.org/10.1007/978-94-017-8902-8_2

10. Flores, M. A. (2018). Teacher resilience in adverse contexts: Issues of professionalism and professional identity. In Resilience in education (pp. 167-184). Springer, Cham. https://doi.org/10.1007/978-3-319-76690$\underline{4 \quad 10}$ 
11. Freidson, E. (2001). Professionalism, the third logic: On the practice of knowledge. University of Chicago press.

12. Goodwin, A. L. (2021). Teaching standards, globalisation, and conceptions of teacher professionalism. European Journal of Teacher Education,44(1), 5-19. https://doi.org/10.1080/0261 9768.2020.1833855

13. Guskey, T. R. (2002). Professional development and teacher change. Teachers and teaching, 8(3), 381-391. https://doi.org/10.1080/135406002100000512

14. Hafferty, F. W., \& Castellani, B. (2010). The increasing complexities of professionalism. Academic Medicine, 85(2), 288-301. https://doi.org/10.1097/ACM.0b013e3181c85b43

15. Hargreaves, A. (2000). Four ages of professionalism and professional learning. Teachers and teaching, 6(2), 151-182. https://doi.org/10.1080/713698714

16. Harwood, D., \& Tukonic, S. (2016). Babysitter or professional? Perceptions of professionalism narrated by Ontario early childhood educators. International Electronic Journal of Elementary Education, 8(4), 589-600.

17. Hoodbhoy, P. (2004). Can Pakistan Work-A Country in Search of Itself. Foreign Aff., 83, 122. https://doi.org/10.2307/20034142

18. Ingersoll, R., Merrill, L., \& May, H. (2011). What are the effects of teacher education and preparation on beginning math and science teacher attrition? In Annual Meeting of the American Educational Research Association, New Orleans.

19. Keddie, A. (2017). Primary school leadership in England: performativity and matters of professionalism. British Journal of Sociology of Education, 38(8), 1245-1257. https://doi.org/10.1080/01425692.2016.1273758

20. Knapp, S., Gottlieb, M. C., \& Handelsman, M. M. (2017). Enhancing professionalism through selfreflection. Professional Psychology: Research and Practice, 48(3), 167. https://doi.org/10.1037/pro0000135

21. Malm, M. (2009). Towards a new professionalism. Journal of Education for Teaching. 35. 77-91. https://doi.org/10.1080/02607470802587160

22. Marom, L. (2019). Under the cloak of professionalism: Covert racism in teacher education. Race Ethnicity and Education, 22(3), 319-337. https://doi.org/10.1080/13613324.2018.1468748

23. Maxwell, B., \& Schwimmer, M. (2016). Seeking the elusive ethical base of teacher professionalism in Canadian codes of ethics. Teaching and Teacher Education, 59, 468-480. https://doi.org/10.1016/j.tate.2 016.07 .015

24. Mayer, D., \& Mills, M. (2021). Professionalism and teacher education in Australia and England. European Journal of Teacher Education, 44(1), 45-61. https://doi.org/10.1080/02619768.2020.1832987

25. Menter, I., \& Flores, M. A. (2021). Connecting research and professionalism in teacher education. European Journal of Teacher Education, 44(1), 115-127. https://doi.org/10.1080/02619768.2020.1856811

26. Mukeredzi, T. G. (2013). Professional Development Through Teacher Roles: Conceptions of Professionally Unqualified Teachers in Rural South Africa and Zimbabwe. Journal of Research in Rural Education, 28(11).117.

27. Newlyn, D. (2014). Should school teaching be classified as a profession? A twenty-first-century look at this classic question. International Journal Of English And Education, 3(1). 531-540.

28. Noordegraaf, M. (2007). From "pure" to "hybrid" professionalism: Present-day professionalism in ambiguous public domains. Administration \& Society, 39(6), 761-785. https://doi.org/10.1177/0095399707304434

29. Pearson, L. C., \& Moomaw, W. (2005). The relationship between teacher autonomy and stress, work satisfaction, empowerment, and professionalism. Educational research quarterly, 29(1), 38-54.

30. Price, H. E., \& Weatherby, K. (2018). The global teaching profession: how treating teachers as knowledge workers improves the esteem of the teaching profession. School Effectiveness and School Improvement, 29(1), 113-149. https://doi.org/10.1080/09243453.2017.1394882

31. Rizvi, M., \& Elliot, B. (2005). Teachers' perceptions of their professionalism in government primary schools in Karachi, Pakistan. Asia-Pacific Journal of Teacher Education, 33(1), 35-52. https://doi.org/10.1080/1359866052000341115

32. Ro, J. (2020). Curriculum, standards and professionalisation: The policy discourse on teacher professionalism in Singapore. Teaching and Teacher Education, 91, 103056. https://doi.org/10.1016/j.tate.2020.103056

33. Sachs, J. (2016). Teacher professionalism: Why are we still talking about it?. Teachers and teaching, 22(4), 413-425. https://doi.org/10.1080/13540602.2015.1082732

34. Sambell, K., Brown, S., \& Graham, L. (2017). Professionalism in practice: key directions in higher education learning, teaching and assessment. Springer. https://doi.org/10.1007/978-3-319-54552-3

35. Sethy, S. S. (2018). Academic ethics: Teaching profession and teacher professionalism in higher education settings. Journal of Academic Ethics, 16(4), 287-299. https://doi.org/10.1007/s10805-018-9313-6

36. Snoek, M., Swennen, A., \& Van der Klink, M. (2009, May). The teacher educator: a neglected factor in the contemporary debate on teacher education. In Proceedings of the TEPE 3rd annual conference teacher education policy in Europe: Quality in teacher education (pp. 288-299). https://doi.org/10.1007/978-1-40208874-2

37. Tatto, M. T. (2021). Professionalism in teaching and the role of teacher education. European Journal of Teacher Education, 1-25. https://doi.org/10.1080/02619768.2020.1849130 
38. Tichenor, M. S., \& Tichenor, J. M. (2009). Understanding teachers' perspectives on professionalism. Professional Educator, 27, 89-95.

39. Torres, A. C., \& Weiner, J. (2018). The new professionalism? Charter teachers' experiences and qualities of the teaching profession. education policy analysis archives, 26, 19. https://doi.org/10.14507/epaa.26.3049

40. Wardoyo, C., \& Herdiani, A. (2017). Teacher Professionalism: Analysis of Professionalism Phases. International Education Studies, 10(4), 90-100. https://doi.org/10.5539/ies.v10n4p90

41. Whitty, M. T. (2008). Revealing the 'real'me, searching for the 'actual you: Presentations of self on an internet dating site. Computers in Human Behavior, 24(4), 1707-1723. https://doi.org/10.1016/j.chb.2007.07.002 